\title{
RAZNOLIKOST I UGROŽENOST TRAVNJAKA NACIONALNOG PARKA SJEVERNI VELEBIT
}

\author{
Antun Alegro \\ Vedran Šegota \\ Botanički zavod, Biološki odsjek \\ Prirodoslovno-matematički fakultet \\ Sveučilište u Zagrebu \\ HR 10000 Zagreb \\ antun.alegro@biol.pmf.hr \\ vedran.segota@biol.pmf.hr
}

\author{
UDK: 58(234Velebit) \\ 633.2.033(234Velebit) \\ Izvorni znanstveni članak \\ 14.10.2019.
}

Travnjaci Nacionalnog parka Sjeverni Velebit većinom nisu primarni tip vegetacije, nego su nastali kao posljedica ljudskog djelovanja krčenjem i paljenjem šuma, ispašom i košnjom. Taj je proces započeo prije više tisućljeća te je kontinuirano održavao ravnotežu između šuma i travnjaka, a rezultirao je većom bioraznolikošću no što bi bila u nedirnutom prirodnom stanju. U drugoj polovici 20. stoljeća tradicionalne sezonske transhumantne vertikalne migracije ljudi i stoke iz Podgorja na velebitske ljetne pašnjake prekinute su kao posljedica snažne depopulacije Podgorja, koje je danas najslabije naseljeno područje u Hrvatskoj. Vegetacijska istraživanja travnjaka unutar Parka tijekom 2009. i 2010. ukazala su na veliku raznolikost travnjaka koji se međusobno razlikuju ovisno o nadmorskoj visini, reljefu terena, značajkama tla, utjecaju vjetra i nekadašnjem načinu upotrebe. Sukcesija, odnosno zarastanje travnjačkih površina drvenastim i grmolikim vrstama zabilježena je na gotovo svim tipovima travnjaka, no intenzitet zarastanja i vrste kojima zarastaju ovise o tipu travnjaka. Sukcesija je značajno sporija na travnjacima vršne zone nego na travnjacima primorske padine zbog kraćega vegetacijskog perioda, oštrije klime, izloženosti buri te prostranijih travnjaka koji sporije zarastaju od manjih, fragmentiranih travnjaka kakve nalazimo na nižim nadmorskim visinama. Očuvanje travnjaka morao bi biti prioritet upravljanja Parkom jer, osim iznimne bioraznolikosti, travnjaci nam ujedno govore i o prošlosti čitava područja, načinu života, privređivanja, kretanja te čine neizostavan i nemjerljivo važan dio prirodne i kulturne baštine.

Ključne riječi: pašnjaci, sukcesija, transhumanca, ispaša

\section{Uvod}

Kada gledamo velebitski krajolik, doživljavamo ga kao mozaik raznolikih staništa - šuma, travnjaka, stijena, sipara i rijetkih vodenih staništa. Naoko nam 
se čini da je taj krajolik oduvijek takav, no stvarnost je potpuno drugačija. Njegov sadašnji izgled posljedica je duga razvoja i raznolikih utjecaja, premda ni on nije statičan, već će se i dalje mijenjati ovisno o nizu čimbenika koje je često teško ili čak nemoguće predvidjeti.

Upravo su travnjaci tip vegetacije iz kojeg možemo iščitati doista mnogo o razvoju i promjenama krajolika. S obzirom na to da su, uz šume, travnjaci najzastupljenija staništa u Parku, u prvi mah može se činiti vrlo neobičnim činjenica da nisu primarni tip vegetacije, nego su nastali kao posljedica ljudskoga djelovanja. Površina prirodnih, primarnih travnjaka u Parku gotovo je zanemariva. Ograničeni su na planinske vrhove i grebene, kose i padine. $\mathrm{Na}$ njima se zbog jakoga utjecaja vjetra, prije svega bure, dugog ležanja snijega ili čestih lavina nije mogla razviti šumska vegetacija. Svi ostali travnjaci nastali su tako da je čovjek krčio i palio šumu kako bi prije svega dobio pašnjake za svoja stada, zatim košanice, obradive površine za uzgoj jestivih kultura i mjesto za svoja naselja, stanove i torove. Taj proces započeo je prije više tisućljeća i zbivao se polako, stalno održavajući ravnotežu između šuma i travnjaka te je rezultirao većom bioraznolikošću no što bi bila u nedirnutom prirodnom stanju. Mnoge biljne vrste ograničene na vrlo male površine prirodnih travnjaka na taj su način dobile veći životni prostor. Neke od njih u davnoj su prošlosti pristigle sa stadima iz drugih, prije svega istočnomediteranskih područja, a nekima su upravo ti travnjaci postali središta njihove evolucije. Tako su čovjek i njegove životinje bili nužni ne samo za stvaranje travnjaka, već i za njihovo održavanje. Uloga stoke u širenju biljaka na nova područja vrlo je velika, a najveću ulogu u tome imaju ovce zbog vune na koju se lako prikvače razni biljni dijelovi, prvenstveno suhi plodovi i sjemenke. Tako stado od četiristo ovaca može prenijeti najmanje tri milijuna sjemenki s jednog na drugi pašnjak ${ }^{1}$. Dakle, osim višestoljetnog održavanja travnjaka ispašom, domaće životinje su i ključan element $u$ transportu sjemenki tijekom stočarskih migracija te je današnji sastav biljnih vrsta na travnjacima upravo rezultat tog procesa ${ }^{2}$. Primjerice, čak polovica biljnih vrsta submediteranskih travnjaka s područja slovenskog krša prenosi se ovčjim runom ${ }^{3}$. U procesu prijenosa sjemenki manju, ali nezanemarivu ulogu imaju i divlje životinje.

Ispaša domaćim životinjama predstavlja tradicionalni način upravljanja travnjacima koji je pomogao njihovom održavanju tisućljećima ljudskog bivanja

${ }^{1}$ S. F. FISCHER et al., 1996, 1206-1222.

${ }^{2}$ H. ELLENBERG, 1998; M. KALIGARIČ et al., 2006, 241-258.

${ }^{3}$ M. KALIGARIČ et al., 2016, 177-184. 
na prostoru Europe. Taj proces nije bio jednoličan. Dapače, ovisio je prvenstveno o vrstama koje su se napasivale, veličini stada te sezonalnosti, učestalosti i trajanju ispaše, a kombinacija svih tih čimbenika ogledala se u izgledu i florističkom sastavu travnjaka. Na području Sredozemlja postoji više različitih sustava ispaše, no većina predstavlja neki vid transhumantnog stočarstva, odnosno selidbe stada stoke na veće, vertikalne ili horizontalne udaljenosti.

Travnjaci Nacionalnog parka Sjeverni Velebit pripadaju skupini tzv. kalcifilnih travnjaka, razvijenih na vapnenačkoj podlozi, koji se u domaćoj stručnoj literaturi najčešće nazivaju kamenjarskim pašnjacima, ukazujući time na ispašu kao glavni čimbenik njihovog održavanja. Kalcifilni travnjaci jedni su od najbogatijih staništa u Europi, a njihov se značaj ogleda u velikoj raznolikosti i bogatstvu biljnih i životinjskih vrsta na jedinici površine. Na jednom kvadratnom metru ovih travnjaka raste i do 50 različitih biljnih vrsta, a ako uključimo i mahovine, lišajeve i gljive, taj broj raste i do $80^{4}$.

U mnogim dijelovima Europe, pogotovo zapadne i srednje, evidentirano je osjetno smanjenje površina pod kalcifilnim travnjacima koje postaju sve fragmentiranije i međusobno izoliranije. Smanjenje površina travnjaka posljedica je dvaju različitih procesa $-\mathrm{s}$ jedne strane intenziviranja poljoprivrede (prenamjena travnjaka u obradive površine), a $\mathrm{s}$ druge strane napuštanja tradicionalnog korištenja tih travnjaka kao pašnjaka. Upravo je ovaj drugi proces smanjenja utjecaja ispaše na travnjake doveo u mnogim dijelovima Europe do širenja drugih tipova vegetacije (šikara i šuma). Trend smanjenja ili potpunog napuštanja ispaše na planinskim područjima prisutan je širom Sredozemlja. Istraživanja u Grčkoj, Italiji i Španjolskoj nedvosmisleno su potvrdila povezanost napuštanja tradicionalne ispaše na sredozemnim planinama $\mathrm{s}$ procesima zarastanja travnjaka (sukcesije) i promjenama u sastavu vrsta ${ }^{5}$.

\section{Stočarska kretanja na Velebitu}

Zbog siromašne prirodne osnove tradicionalno se podgorsko gospodarstvo zasnivalo na ekstenzivnom stočarstvu te obradi ponikava i udolina u kojima se tlo branilo kamenim suhozidima. Budući da su obradive površine bile rijetke i oskudne, stočarstvo je bilo važnije od poljodjelstva ${ }^{6}$. Iscrpan pregled stočarenja i pašnjaštva na Velebitu nalazi se u nizu publikacija ${ }^{7}$. Za razumijevanje stočarskih

\footnotetext{
${ }^{4}$ M. J. HUTCHINGS - A. J. A. STEWART, 2002.

${ }^{5}$ V. P. PAPANASTASIS - D. CHOUVARDAS, 2005, 191-202.

${ }^{6}$ M. KLEMENČIĆ, 2017, 5-16.

${ }^{7}$ M. MARKOVIĆ, 1971, 1975, 1980, 2003; Ž. POLJAK, 1969.
} 
kretanja na Velebitu nužno je pojasniti visinske zone koje su stočari koristili. Najniža zona do $200 \mathrm{~m} \mathrm{n}$. v. je primorje i predstavlja područje selišta, odnosno matičnih domaćinstva Primoraca, gdje je stoka boravila od jeseni do proljeća. Od 200 do 500 , odnosno 500 do $900 \mathrm{~m}$ n. v. nalaze se podgorje i podi, tj. područje etapnih boravišta, tzv. sezonskih stanova, gdje je stoka boravila u kasno proljeće i dio ljeta, a ponekad i tijekom blažih zima. Slijedi nadgorje (900 do $1300 \mathrm{~m} \mathrm{n}$. v.), područje ljetnih pašnjaka, prostorno najveće površine na Velebitu. Na najvišim nadmorskim visinama (1300 do $1700 \mathrm{~m} \mathrm{n}$. v.) je vrhgorje gdje su planinski pašnjaci korišteni tek krajem ljeta. Pašnjačka vegetacija porastom apsolutne visine zbog svježijih i vlažnijih uvjeta postaje sve obilnija, a optimalno razvijena ljeti kad na nižim nadmorskim visinama vlada najizrazitija suša.

Na području današnjeg Nacionalnog parka Sjeverni Velebit bila su važna dva tradicionalna pravca stočarskih kretanja: "izdig" iz Kvarnerskog primorja na planinske pašnjake sjevernog Velebita te "zdig" Ličana, također na planinske pašnjake sjevernog Velebita, s time da Primorci i Ličani nisu koristili iste pašnjake, već su ih običajnim pravom međusobno podijelili. Velebitski stočarski putovi imali su dva glavna smjera: poprečni - od mora prema Lici i uzdužni usporedni sa smjerom pružanja planine. Poprečnih putova ima više jer spajaju primorska i lička naselja, prolazeći preko prirodnih prijelaza, klanaca i prijevoja. Preko sjevernog Velebita tri su glavna poprečna stočarska pravca: najsjeverniji pravac koji povezuje Lukovo s Krasnom (preko Adžića krča i Božina plana do Jezera, preko Nadžak bila do Krasna), južniji pravac koji povezuje selo Kladu s Krasnom i Jezerima (preko Babrovače i izlazi na Vučjak) te najjužniji pravac od Stinice preko Dundović poda za Alan, gdje zakreće prema Tudorevu i Lubenovcu.

\section{Depopulacija i napuštanje stočarstva}

Podgorje (područje jadranske obale u podnožju Velebita koje obuhvaća naselja Grada Senja te općine Karlobag i Starigrad) karakteriziraju vrlo negativna demografska obilježja. Ukupna depopulacija traje od 1910. godine kada je zabilježen maksimum naseljenosti od 16782 stanovnika. Taj se broj u sljedećih sto godina prepolovio pa je, prema popisu iz 2011., u Podgorju živjelo svega 8894 stanovnika $^{8}$. Ova drastična promjena zorno se vidi u padu broja stanovnika po pojedinim podgorskim naseljima. Primjerice, u Stinici je 1900. godine živjelo 1345 , a 2011. tek 83 stanovnika, u Volaricama je u tom razdoblju broj opao s 1022 na 86, u Jablancu s 914 na 83, u Starigradu s 578 na 15, u

\footnotetext{
${ }^{8}$ I. TURK et al., 2017, 73-96.
} 
Kladi s 500 na 39 a u Lukovu s 448 na 36 stanovnika9. Stalna depopulacija i negativni prirodni prirast doveo je i do izumiranja stanovnika u nekim naseljima, primjerice u Velikim Brisnicama ${ }^{10}$. Gustoća stanovništva Podgorja 2011. godine bila je manja od 10 stanovnika po četvornom kilometru, a ako isključimo Senj, gustoća pada na manje od pet stanovnika po četvornom kilometru, što u oba slučaja ukazuje da je Podgorje najrjeđe naseljeni dio Hrvatske ${ }^{11}$. Čitavo područje određuje deagrarizacija što je rezultiralo emigracijom i depopulacijom ${ }^{12}$. Nekada dominantne djelatnosti poljoprivreda, ribarstvo i stočarstvo, zamijenili su turizam, trgovina i ugostiteljstvo, manje proizvodnja ${ }^{13}$.

\section{Ciljevi istraživanja}

Svrha ovoga istraživanja bila je ustanoviti koji tipovi travnjaka postoje na području Nacionalnog parka Sjeverni Velebit te istražiti jesu li (i ako jesu, u kojoj mjeri) zahvaćeni procesima zarastanja i kojim drvenastim vrstama.

\section{Materijal i metode}

Terenska istraživanja travnjaka obavljena su tijekom vegetacijske sezone 2009. i 2010. godine. Istraživani su travnjaci vršne zone (Šegotski i Bilenski padež, Tudorevo, Mirovo, Rožano, Lubenovac, Zavižan, uz Premužićevu stazu) te primorske padine (Dundovića pod, Žive vodice, Babrovača, Paljež, Modrić dolac, Javorje, Jasenje/Gobanovića padež, Pandorina plan, Alan, Oštrik, Zelengrad, Babić sića, Markov kuk, Dešinovac, Zlatkine njive, Ječmište, Struge, Lađa kod Vujinačkih greda, Vujinac, Vukušić duliba, Borove vodice, Zabudim, Plančica, Laminača i ispod Buljme).

Za svaki travnjak na kojem se opisivala vegetacija ili radila vegetacijska fitocenološka snimka uzimane su koordinate pomoću GPS uređaja, zabilježen je vegetacijski tip, sve travnjačke vrste, vrste drveća i grmlja kojima zarasta te ostali podaci (ekspozicija, nagib, eventualni način iskorištavanja i dr.). Istraživalo se ukupno 195 lokaliteta na travnjacima Parka (Sl. 1.), od čega je na 125 učinjena vegetacijska snimka (popis vrsta i njihove pokrovnosti) prema standardnoj srednjoeuropskoj metodi, pomoću proširene Braun-Blanquetove skale za

\footnotetext{
${ }^{9}$ I. TURK et al., 2017, 73-96.

${ }^{10}$ J. BRAJKOVIĆ, 2017, 195-214.

${ }^{11}$ M. KLEMENČIĆ, 2017, 5-16

${ }^{12}$ J. BRAJKOVIĆ, 2017, 195-214.

${ }^{13}$ J. BRAJKOVIĆ, 2017, 195-214.
} 


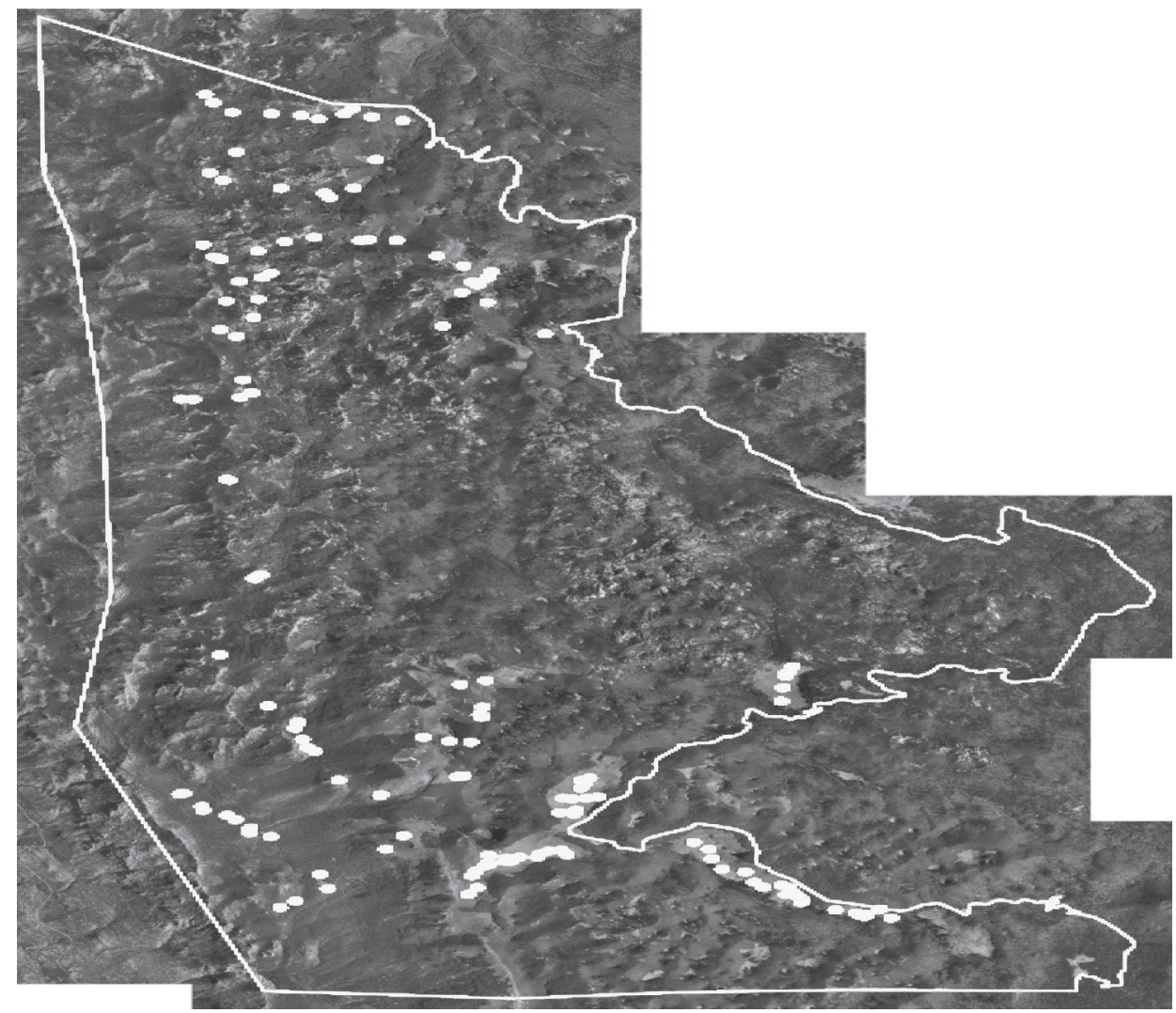

S1. 1. Istraživani lokaliteti na travnjacima u Nacionalnom parku Sjeverni Velebit na satelitskoj snimci (URL: https://hirc.botanic.hr/fcd/)

kombiniranu procjenu abundancije i pokrovnosti $\operatorname{vrsta}^{14}$. Snimke su snimane na površini od 50 do $100 \mathrm{~m}^{2}$. Nazivlje svojti usklađeno je s bazama podataka Flora Croatica ${ }^{15}$ i The Plant List ${ }^{16}$, a sintaksona s relevantnom vegetacijskom literaturom ${ }^{17,18,19}$.

\footnotetext{
${ }^{14}$ J. BRAUN-BLANQUET, 1964; J. J. BARKMAN et al., 1964, 394-419; H. DIERSCHKE,
} 1994.

${ }^{15}$ T. NIKOLIĆ, 2019.

${ }^{16}$ The Plant List, 2013.

${ }^{17}$ I. HORVAT et al., 1974.

${ }^{18}$ I. TRINAJSTIĆ, 2008.

${ }_{19}$ Pravilnik o popisu stanišnih tipova, karti staništa te ugroženim i rijetkim stanišnim tipovima, 2014. 


\section{Rezultati i rasprava}

Iako su travnjaci Nacionalnog parka Sjeverni Velebit nastali djelovanjem čovjeka, nisu svi isti. Razlikuju se ovisno o nadmorskoj visini, reljefu terena, značajkama tla, utjecaju vjetra, načinu upotrebe i drugim čimbenicima koje je ponekad teško otkriti. Međuigra ovih čimbenika stvorila je niz travnjačkih tipova, koji se odlikuju i specifičnom kombinacijom biljnih vrsta. Sukcesija, odnosno zarastanje travnjačkih površina s drvenastim i grmolikim vrstama zabilježena je na gotovo svim tipovima travnjaka, no intenzitet zarastanja i vrste kojima zarastaju ovise o tipu travnjaka.

Na području Nacionalnog parka evidentirali smo sljedeće tipove travnjaka i sukcesije na njima:

1. Kamenjarski pašnjaci s vriskom (sveza Saturejon subspicatae Horvatić 1975) koji se na primorskim padinama javljaju u rasponu od 800 do $1400 \mathrm{~m} \mathrm{n}$. v. To su kamenjarski pašnjaci redovno razvijeni na nagnutim terenima, često vrlo skeletnim i krševitim, tako da mjestimice prelaze u sipare. U njima ne dominiraju trave, nego polugrmovi vrisaka (Satureja subspicata i S. montana, kao i njihov križanac $S . \times$ karstiana), žutilovki (Genista sericea, G. sylvestris), krestušca (Polygala niccaeensis), dubačaca (Teucrium chamaedrys i T. montanum), glavulje (Globularia cordifolia) i drugih, a od "travolikih" biljaka obilno je zastupljen šaš crljenika (Carex humilis). Od pravih trava tu dolazi uspravni ovsik (Bromus erectus agg.), no nikad vizualno ne dominira u sastojinama. S obzirom na širok raspon nadmorskih visina u kojima se javljaju, unutar kamenjarskih pašnjaka s vriskom mogu se razlikovati dvije zajednice:

1a. Kamenjarski pašnjaci šaša crljenike i žute krške zečine (asocijacija Carici humilis-Centauretum rupestris Horvat 1931) razvijeni su na nižim nadmorskim visinama od oko 800 do 900 m (Dundović pod, Kačarica, Laminača, Turska vrata). Za njih je značajan veliki udio submediteranskih vrsta, koje se često javljaju s velikim populacijama, npr. žuta krška zečina (Centaurea rupestris), velecvjetni krestušac (Polygala nicaensis), glavatka (Cephalaria leucantha), modri kotrljan (Eryngium amethystinum), sjajna smilica (Koeleria splendens) i druge.

1b. Kamenjarski pašnjaci vriska i šaša crljenike (asocijacija Saturejo subspicatae-Caricetum humilis Trinajstić (1981) 1999, corr. 2007) zauzimaju više položaje u rasponu visina od oko 1100 do $1400 \mathrm{~m}$. Proučavani su na području Borovih vodica, Vukušić dulibe, Zelengrada, Oštrika, Alančića i Buljme. Za njih je značajno da većina od submediteranskih vrsta obilno zastupljenih u prethodnoj zajednici izostaje, tako da su floristički siromašniji. 
Umjesto njih javljaju se neke od vrsta viših položaja kao što su jaglac (Primula veris ssp. columnae), pustenasta zečina (Centaurea triumphetti), srebrnolisni trputac (Plantago argentea), tršćanski srčanik (Gentiana tergestina) i neke druge.

Iako se radi o kamenjarskim travnjacima te je zbog skeletnosti tla za očekivati sporo zarastanje, to nažalost nije slučaj. Kamenjarske pašnjake zarasta vjerojatno najveći broj drvenastih vrsta. Škrto tlo ne dozvoljava razvoj visokog drveća, no razvija se šikara koja može biti gusta i doslovce neprohodna. Te šikare čine šmrika (Juniperus oxycedrus), crni jasen (Fraxinus ornus), crni bor (Pinus nigra), smrdljiva borovica (Juniperus sabina), merala (Amelanchier ovalis), srednja krkavina (Rhamus intermedia), glog (Crataegus monogyna), rašeljka (Prunus mahaleb), crni grab (Ostrya carpinifolia), drijenak (Cornus mas) i sinja ruža (Rosa glauca). Ovakve šikare karakteristične su prvenstveno za niže položaje, odnosno za područje rasprostranjenosti kamenjara šaša crljenike sa žutom krškom zečinom. U kamenjarima viših položaja, tj. u zajednici vriska i šaša crljenike, zbog oštrije klime i jačeg utjecaja vjetra zarastanje je znatno sporije i u njemu sudjeluje manji broj vrsta. Od njih treba istaknuti smrdljivu borovicu (Juniperus sabina), crni bor (Pinus nigra), bor krivulj (Pinus mugo), jarebiku (Sorbus aucuparia) i osobito patuljastu borovnicu (Juniperus communis subsp. nana).

2. Travnjaci isprekidane šašike $i$ šaša crljenike (asocijacija Seslerio juncifoliae-Caricetum humilis Horvat 1930) vrlo su prepoznatljivi i rasprostranjeni travnjaci primorskih padina i vršne zone Nacionalnog parka Sjeverni Velebit. Inače, taj tip travnjaka s vrstama iz agregata Sesleria juncifolia rasprostranjen je u Hrvatskoj čitavim lancem Dinarida od Snježnika do Sniježnice (u Konavlima), dok se cjelokupni areal proteže od Slovenskog Snežnika do planina sjeverne Albanije. To je tipičan ilirski areal pa možemo reći da je ovo karakteristična ilirska zajednica. Ovo je pašnjački travnjak najviših položaja primorskih padina izloženih buri, a razvija se u pojasu od oko $1200 \mathrm{~m} \mathrm{n}$. v. do najviših vrhova (npr. Balinovac 1602 m n. v., Veliki Zavižan 1676 m n. v., Oštrik, 1355 m n. v., Alančić 1611 m n. v., Buljma $1451 \mathrm{~m} \mathrm{n}$. v.). Rudine s isprekidanom šašikom najrasprostranjeniji su tip visokoplaninskih travnjaka primorskih padina Velebita, a za njihovo pojavljivanje odlučujuća je jaka bura. U takvim uvjetima konkurentna je upravo isprekidana šašika, pa je ona ujedno i dominantna vrsta. Na zaklonjenijim položajima konkurentnije su neke druge vrste trava, tako da se razvijaju i druge zajednice, prije svega kamenjarski travnjaci s vriskom. Šašici se s nešto većom učestalošću može primiješati šaš crljenika (Carex humilis), dok se ostale vrste javljaju s manjom brojnošću. Takva monodominantna, jednolična građa zajednice 


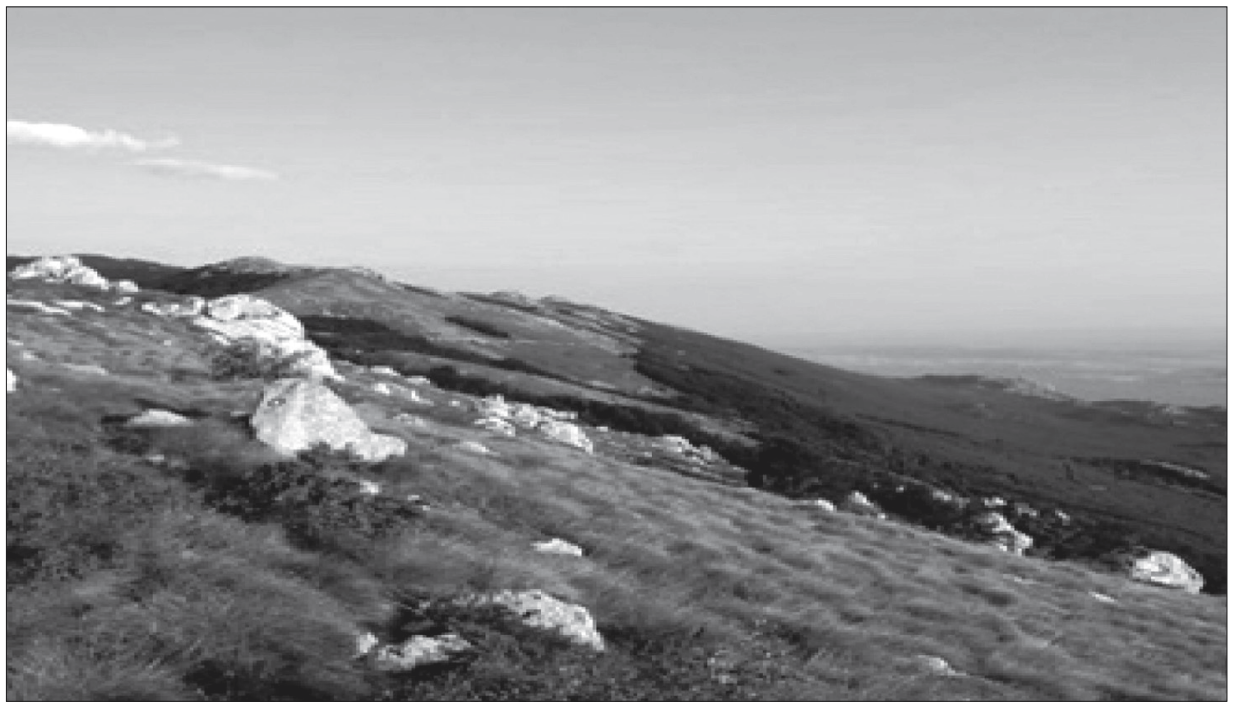

S1. 2. Travnjaci isprekidane šašike i šaša crljenike (snimio Antun Alegro, 2010.)

odraz je ekstremnih uvjeta u kojima se razvija. Od ostalih biljaka koje se javljaju u ovoj zajednici valja još spomenuti vrste svilenasta žutilovka (Genista sericea), hrapavodlakavi oman (Inula hirta), planinski vrisak (Satureja subspicata), srcolika glavulja (Globularia cordifolia), srebrnolisni trputac (Plantago argentea), planinski ušljivac (Pedicularis hoermaniana), glatka dvoštitka (Biscutella laevigata), velebitska oštrica (Oxytropis dinarica subsp. velebitica) i druge.

Kao i prethodni, i ovi travnjaci se razvijaju u ekstremnim ekološkim uvjetima, s tom razlikom da ovdje nije odlučujuć kemizam tla, nego jaka bura. Na buri izloženim padinama uvjeti za život drvenastih vrsta su teški, tako da se ti travnjaci uglavnom doimaju kao velike jednolične travnate površine. No, iako na njima nema uspravnog drveća obilno se razvijaju niski puzavi grmovi medvjetke, lokalno zvana bejavica (Arctostaphyllos uva-ursi) i patuljaste borovice (Juniperus communis subsp. nana). Od ostalih drvenastih vrsta tu se još javljaju merala (Amelanchier ovalis), dunjarica (Cotoneaster integerrimus), smrdljiva borovica (Juniperus sabina), jarebika (Sorbus aria agg.), smreka (Picea abies), crni bor (Pinus nigra), a na račun ovih travnjaka se šire i klimatogene zajednice pretplaninskih bukovih šuma i klekovine bora.

3. Travnjaci s dominacijom uspravnog ovsika (sveza Bromion erecti W. Koch 1926) su vrlo rasprostranjena i specifična travnjačka zajednica u Nacionalnom parku Sjeverni Velebit. Ovi travnjaci nisu vezani uz nagnute 
izložene padine, nego uz zaravnjene dolce. Pretežno se nalaze u rasponu nadmorskih visina od 850 do $1100 \mathrm{~m}$ te nisu direktno eksponirani moru ili buri, već se nalaze na zaštićenim položajima i često su okruženi šumom. Razvijaju se nad dubljim tlima koja nikad nisu kamenjarska, ali su s druge strane dovoljno plitka da ne dođe do ispiranja i zakiseljavanja na što upućuje izostanak acidofilnih vrsta. Ovi travnjaci vjerojatno su različitog postanka. Većim dijelom su se vjerojatno koristili kao pašnjaci (na području Babrovače i Palježi koriste se i danas), a kako se nalaze na zaravnjenim terenima bez stršećeg kamenja, moguće je da su služili i kao košanice. Manji dio tih travnjaka mogao je nastati i zarastanjem nekad obrađivanih površina (npr. na Dundović podu i na terasama kod Gobanović padeža). Karakterizira ih relativno opsežan skup vrsta, a neke od njih su hrptasti luk (Allium carinatum), bodljičasta krvara (Sanguisorba minor ssp. muricata), gomoljasta končara (Filipendula vulgaris), ljekoviti čistac (Betonica officinalis ssp. serotina), livadna kadulja (Salvia pratensis) i druge.

Ovo je sukcesijom najugroženiji tip travnjaka i to iz više razloga. Travnjaci uspravnog ovsika ne razvijaju se u ekološki ekstremnim uvjetima, nego naprotiv na zaštićenim, zaravnjenim položajima, nad nešto dubljim (ili barem ne kamenjarskim) tlima koja nisu isprana, što su sve vrlo povoljni uvjeti za naseljavanje drvenastih vrsta. S druge strane dio tih travnjaka nalazi se u blizini šuma crnog bora (osobito oni na području Zlatkinih njiva i Ječmišta), koji se vrlo uspješno usijava na njih i tvori iznimno guste, često neprohodne sastojine. I konačno, ti travnjaci često su razvijeni na malim površinama koje stoga brzo zarastaju. Jedan dio ovih travnjaka gotovo je u potpunosti nestao, npr. na području Zlatkinih njiva, Ječmišta i Malenjaka. Od vrsta koje nadiru na travnjake treba spomenuti crni bor (Pinus nigra), javor gluhač (Acer obtusatum), jarebike (Sorbus aria i S. aucuparia), patuljastu borovicu (Juniperus communis subsp. nana), malinu (Rubus idaeus) i druge. Šume bukve koje često okružuju dolce, također zauzimaju obodne dijelove travnjaka. Kod ovog tipa travnjaka treba istaknuti zarastanje s trnovitom ružom (Rosa pimpinellifolia), koja upravo ovdje tvori najgušće sastojine.

4. Travnjaci oštre vlasulje (asocijacija Festucetum bosniacae Horvat 1930) su najrasprostranjeniji tip travnjaka vršne zone Nacionalnog parka Sjeverni Velebit, a ujedno je to i najrasprostranjeniji travnjački tip na rudinama hrvatskih Dinarida. Danas je taj tip travnjaka prisutan na velikim površinama koje su nekad pripadale pretplaninskim šumama bukve, rjeđe smreke i klekovini bora krivulja. Tijekom dugih stoljeća i tisućljeća te su šumske sastojine krčene i paljene kako bi se dobili ljetni pašnjaci, na koje su se stada uzdizala u kolovozu 
i tamo boravila oko mjesec dana. Travnjaci na pogodnom terenu služili su i kao košanice. Prvobitna prirodna staništa ove travnjačke zajednice mjesta su na kojima je snježni nanos i spuštanje lavina toliko, da se ne može razviti niti šuma niti klekovina ${ }^{20}$. Za travnjake oštre vlasulje značajno je da su na zaštićenim položajima, prije svega pošteđenim jake bure, a ponekad i na nešto dubljim, no ne i ispranim tlima. Takva staništa često su zimi zaštićena debelim pokrovom snijega. Takvi prostrani zaštićeni položaji nalaze se u Dundović, Šegotskom i Bilenskom padežu te na dijelovima travnjačkih kompleksa Rožana te širem području Zavižana. Na Tudorevu i Velikom Lubenovcu travnjaci oštre vlasulje mozaično su raspoređeni s drugim tipovima travnjaka s kojim ih veže i niz prijelaznih oblika. U svom sastavu, uz oštru vlasulju, ujedinjuju niz planinskih vrsta, npr. velebitski klinčić (Dianthus velebiticus), kamenjarska pušina (Silene saxifraga), svjetlucava zvjezdoglavka (Scabiosa lucida), bebijski karanfil (Dianthus bebius), kamenjarska bedrenika (Pimpinella alpina), crvenkasti zmijak (Scorzonera rosea), divokozjački staračac (Senecio doronicum), livadna zvončika (Campanula glomerata), okruglolisna zečica (Phyteuma orbiculare), gomoljičasti dvornik (Polygonum viviparum), uskolisni šuškavac (Rhinathus aristatus), planinski ranjenik (Anthyllis vulneraria subsp. alpestris), planinska gorska metvica (Acinos alpinus) i dr. No, s obzirom na to da su redovito razvijeni na zaštićenijim položajima ili bar van direktnog utjecaja bure, na njima nalazimo i niz vrsta koje su inače svojstvene za niže položene, termofilnije travnjake s uspravnim ovsikom. To su npr. uspravni ovsik (Bromus erectus), gorska djetelina (Trifolium montanum), kitnjasta potkovica (Hippocrepis comosa), piramidalna smilica (Koeleria pyramidata), proljetni šaš (Carex caryophyllea), šaš crljenika (Carex humilis) itd.

$\mathrm{Na}$ travnjacima oštre vlasulje možemo pratiti dva osnovna sukcesijska puta uvjetovana različitim ekspozicijima. Ti sukcesijski putovi osobito su dobro vidljivi u Šegotskom i Bilenskom padežu s obzirom na to da imaju gotovo idealno položene padine eksponirane na sjever, odnosno jug. Sjeverno eksponirane padine su zasjenjenije i hladnije tako da na njih počinju prodirati smreke. One se šire ili iz smrekovih šuma koje obrubljuju travnjake ili se naseljavaju kao pojedinačna stabla izrasla iz sjemenki nanesenih vjetrom. Ako se radi o širenju šume, jasno se vidi kako udaljavanjem od šumskog ruba počinju prevladavati sve mlađa stabla i stabalca smreke. Smreku prate i druge šumske vrste, prije svega trava šarena šašuljica (Calamagrostis varia), a zatim žabnjak kolovrc (Ranunculus thora), gorski osjak (Cirsium montanum),

${ }^{20}$ I. HORVAT, 1931, 76-90. 


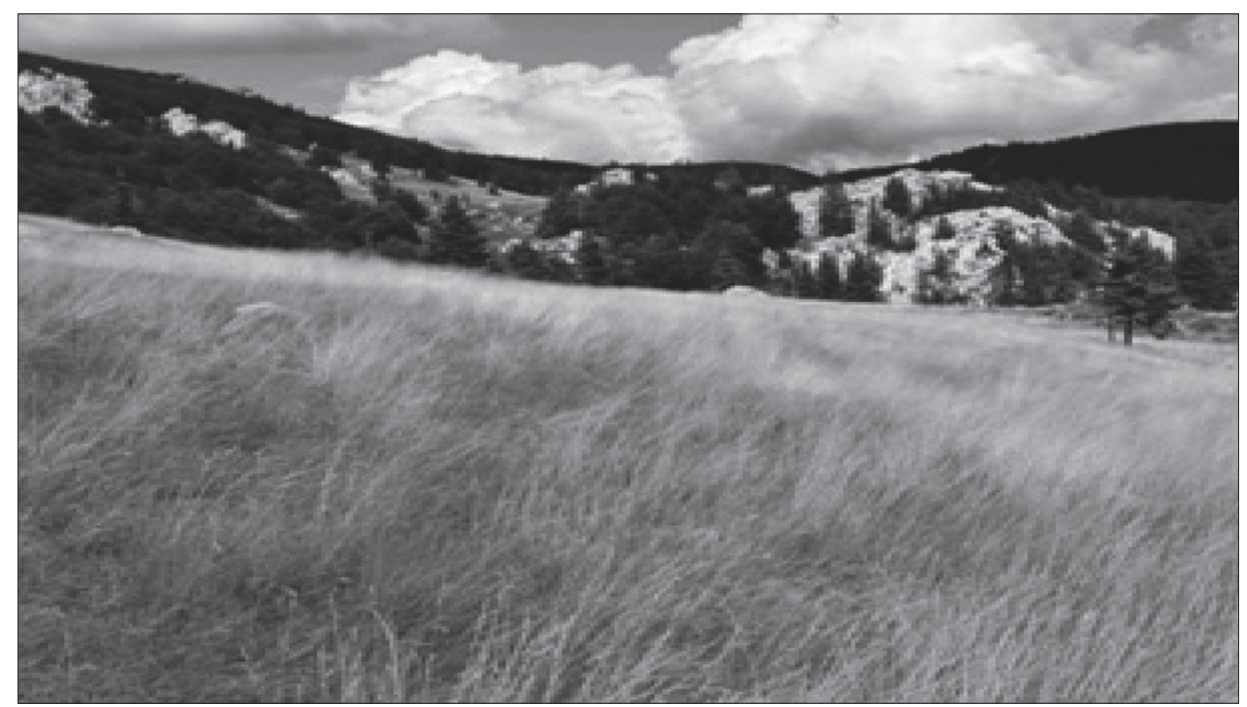

Sl. 3. Travnjak oštre vlasulje u okolici Zavižana (snimio Antun Alegro, 2010.)

borovnica (Vaccinium myrtillus), velelisna vrba (Salix appendiculata), bijela šumarica (Anemone nemorosa) i niz vrsta mahovina. Kako sukcesija napreduje, gubi se oštra granica između šume i travnjaka te nastaje prijelazna zona rijetke mlade šume/zaraslog travnjaka u kojoj se miješaju biljke obje zajednice. Daljnjim razvojem šume stanište se zasjenjuje, stvara se sloj otpalih iglica na tlu što dovodi do potpunog potiskivanja travnjačkih vrsta i formiranja tipične šumske zajednice.

Drugi sukcesijski put karakterističan je za južno eksponirane padine. Taj put nije toliko očit kao zarastanje u smreku jer u njemu glavna vrsta koja prerasta travnjak nije drvenasta, nego polugrm zrakaste žutilovke (Genista radiata). Iako tek neznatno nadrasta travnjačke vrste, zrakasta žutilovka stvara vrlo guste sastojine te ih tako potiskuje. Tako nastaju površine koje izdaleka izgledaju poput travnjaka, no zapravo se radi o vrlo gustoj niskoj šikari koja više nema strukturu travnjaka. Kako su južno eksponirane travnjačke padine obično obrubljene šumama bukve, ona počinje prodirati na takve površine i dodatno mijenjati stanište.

5. Travnjaci s dominacijom metličaste vlasulje (sastojine s Patzkea $(=$ Festuca $)$ paniculata $)$ nalaze se unutar područja rasprostranjenosti travnjaka oštre vlasulje, ali na dubljim, vlažnijim, višeili manje ispranim tlima uvjetovanim reljefom i ekspozicijom. Ti travnjaci vrlo se jasno ističu s obzirom na to da ih 
čine guste monodominantne sastojine metličaste vlasulje koja je nerijetko viša od $1,5 \mathrm{~m}$. Zanimljivo je i pojavljivanje nekih inače tipično šumskih vrsta u ovim travnjacima kao što su bijela šumarica (Anemone nemorosa), kranjska mlječika (Euphorbia carniolica) i gronjasti vratić (Tanacetum corymbosum), zatim vrste koje redovito pridolaze na travnjacima oštre vlasulje, ali izostaju na travnjacima metličaste vlasulje (Thymus praecox, Rhinanthus aristatus, Acinos alpinus, Anthyllis vulneraia subsp. alpestris i niz drugih), te potpuni izostanak termofilnih vrsta. Travnjaci metličaste vlasulje jedan su od najrjeđih tipova planinskih travnjaka u Hrvatskoj, a dosad su poznati jedino s južnih padina Šegotskog i Bilenskog padeža te istočnih padina Tudoreva.

Ovaj tip travnjaka zasad je najmanje ugrožen sukcesijom. Guste i bujne sastojine metličaste vlasulje priječe razvoj grmolikih i drvenastih vrsta. Izostaju čak i Juniperus communis subsp. nana i Rosa pendulina, inače redovno rasprostranjene vrste na susjednim travnjacima oštre vlasulje.

6. Travnjaci tvrdače (asocijacija Nardetum strictae Horvat 1930) razvijaju se $u$ istom tom vršnom pojasu, no na dnima zaravnjenih, zaštićenih dolaca gdje se skupio deblji sloj tla, koji je izolirao vapnenačku podlogu te omogućio ispiranje baza i stvaranje zakiseljene, hranjivima siromašne podloge. Oni su jedini tip acidofilnih travnjaka na području Nacionalnog parka Sjeverni Velebit. Lako su prepoznatljivi po gustim sastojinama trave tvrdače (Nardus stricta), koja je redovno dominantna vrsta. Uz tvrdaču sa znatnom brojnošću pridolaze crnkasta vlasulja (Festuca nigrescens), zečji šaš (Carex leporina), pustenasti šaš (C. tomentosa), poljska bekica (Luzula campestris), petolist srčenjak (Potentilla erecta), planinska mirisavka (Anthoxanthum alpinum), obična rosulja (Agrostis capillaris), dvodomna bubica (Antennaria dioica), šumska smilika (Gnaphalium sylvaticum), puzava čestoslavica (Veronica officinalis), mala kiselica (Rumex acetosella) i druge. U florističkom sastavu uglavnom nema submediteranskih, ilirskih i južnoeuropskih vrsta. Travnjaci tvrdače nisu prirodni travnjaci, već su nastali potiskivanjem šume i klekovine kako bi se dobile pašnjačke površine te predstavljaju maksimum vegetacijske regresije ${ }^{21}$ $\mathrm{s}$ obzirom na to da je uklanjanje šume omogućilo ispiranje i zakiseljavanje tla, a time i stvaranje vrlo nepovoljnih ekoloških prilika za velik broj biljnih vrsta. Zbog svega toga, riječ je o travnjacima vrlo niskog prinosa. Ovi travnjaci na manjim ili većim, no nikad prostranim površinama, razvijeni su na dnima Šegotskog i Bilenskog padeža, Lubenovca, Tudoreva, Rožana i Zavižanskog područja, a daleko najveći travnjak tvrdače nalazi se na Pandorinoj plani.

${ }^{21}$ I. HORVAT, 1930, 1-96. 


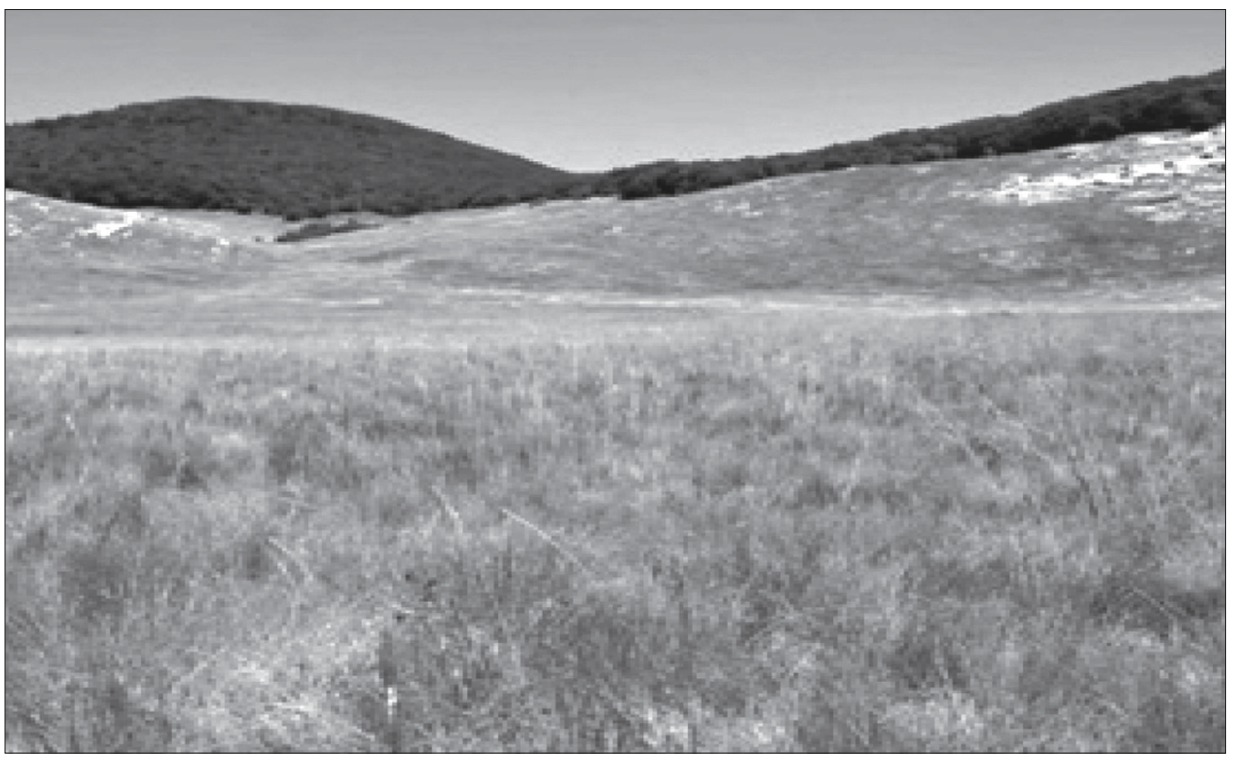

S1. 4. Travnjak tvrdače na Tudorevu (snimio Antun Alegro, 2010.)

Kako se travnjaci tvrdače razvijaju na ispranim, siromašnim, zakiseljenim tlima, koja nisu osobito pogodna za mnoge biljne vrste, i sukcesija je na njima razmjerno spora. Njihov čest smještaj na mrazištima dna dolaca također usporava sukcesiju. No ipak, širenje patuljaste borovice (Juniperus communis subsp. nana) u kao sag gustim, uz tlo prileglim sastojinama mijenja strukturu ove zajednice. Na sukcesiju upućuju i neke zeljaste vrste koje se mjestimice obilnije javljaju, kao što je npr. gospina trava (Hypericum perforatum). Od uspravnih grmova javlja se malina (Rubus idaeus), dok su drugi grmovi i stabla rijetki.

7. Pretplaninski travnjaci busike (asocijacija Deschampsietum subalpinum Horvat 1962 nom. illeg.) razvijaju se ako su dna dolaca ljevkasta, tako da se u njima sakuplja voda, osobito snježnica. Redovito su vrlo malih površina i vrlo siromašnog florističkog sastava. Karakterizira ih monodominantno i bujno razvijena busika (Deschampsia caespitosa) uz koju pridolaze i druge mezofilne vrste, no redovno znatno slabije zastupljene obična rosulja (Agrostis capillaris), crnkasta vlasulja (Festuca nigrescens), livadna kukavičica (Lathyrus pratensis), ivanjsko cvijeće (Galium verum), stolisnik (Achillea millefolium), trokutnolisna loboda (Chenopodium bonus-henricus) te tvrdača (Nardus stricta). 
S obzirom na to da se radi o tipu vegetacije uvjetovane visokom količinom vode, većina vrsta grmlja i drveća koje inače prve koloniziraju travnjake ovdje ne nalaze odgovarajuće uvjete za život. Nadalje, s obzirom na to da se radi o vrlo malim i fragmentarnim površinama, teško je uočiti neki jedinstveni obrazac promjena. Općenito se može reći da te travnjake mogu kolonizirati vrste visokih zeleni, obično jedna do dvije vrste na jednom travnjaku. To npr. mogu biti livadna šapika (Heracleum sphondylium), trokutnolisna loboda (Chenopodium bonus-henricus) i dr.

8. Travnjačke sastojine s dominacijom uspravnog ovsika (Bromus erectus agg.) i šaša crljenike (Carex humilis) javljaju se kao najtermofilniji tip travnjaka vršne zone, redovno iznad vrlo plitkih krševitih tala ili iznad morenskog materijala. Od travnjaka oštre vlasulje razlikuju se većom kontinentalnošću i termofilnošću vrsta koje ih čine. To se može objasniti time što su ti travnjaci razvijeni na vrlo plitkim tlima, ponekad i kršu, zbog čega su ljeti izrazito suhi, što se upravo zbiva i na kontinentalnim stepskim travnjacima. U ovom je slučaju ta pojava uzrokovana lokalnim pedološkim prilikama, a ne klimom. Takvi travnjaci osobito su lijepo razvijeni na Mirovu, gdje su i dominantan tip travnjačke vegetacije, a zatim se u mozaiku s travnjacima oštre vlasulje javljaju na Tudorevu i Lubenovcu. Radi se o sastojinama u kojima u potpunosti izostaje oštra vlasulja, ali preostaje niz drugih vrsta karakterističnih za zajednicu travnjaka oštre vlasulje, a s njima pridolazi i skup termofilnijih vrsta inače obilnije zastupljenih na manjim visinama primorske padine. To su prije svega Bromus erectus i Carex humilis, zatim dlakava roščićava djetelina (Lotus corniculatus subsp. hirsutus), srednji trputac (Plantago media), srebrnolisni trputac (Plantago argentea), gorska djetelina (Trifolim montanum), modrozelena srdiška (Trinia glauca), srcolika glavulja (Globularia cordifolia), kitnjasta potkovica (Hippocrepis comosa), petolist srčenjak (Potentilla erecta), planinski vrisak (Satureja subspicata) i druge. Ovi travnjaci korišteni su kao pašnjaci, a na Mirovu su ispresijecani torištima te većim i manjim obradivim površinama.

S obzirom na to da se javljaju iznad vrlo plitkih i krševitih tala koja su time i ocjedita, sukcesija je na ovom tipu travnjaka relativno neizražena, barem što se tiče visokih grmova i drveća. Međutim, vrlo je izraženo zarastanje u patuljastu borovicu (Juniperus communis subsp. nana), koja poput gustog saga prekriva mjestimice relativno velike površine ovih travnjaka. Svojim izrazito gustim i prileglim sklopom onemogućava razvoj travnjačkih vrsta, oduzima im životni prostor te na taj način mijenja strukturu travnjačke zajednice. $\mathrm{Na}$ isti način se ponaša i medvjetka (Arctostaphylos uva-ursi), no ona se na ovom tipu travnjaka javlja nešto rjeđe od patuljaste borovice. 


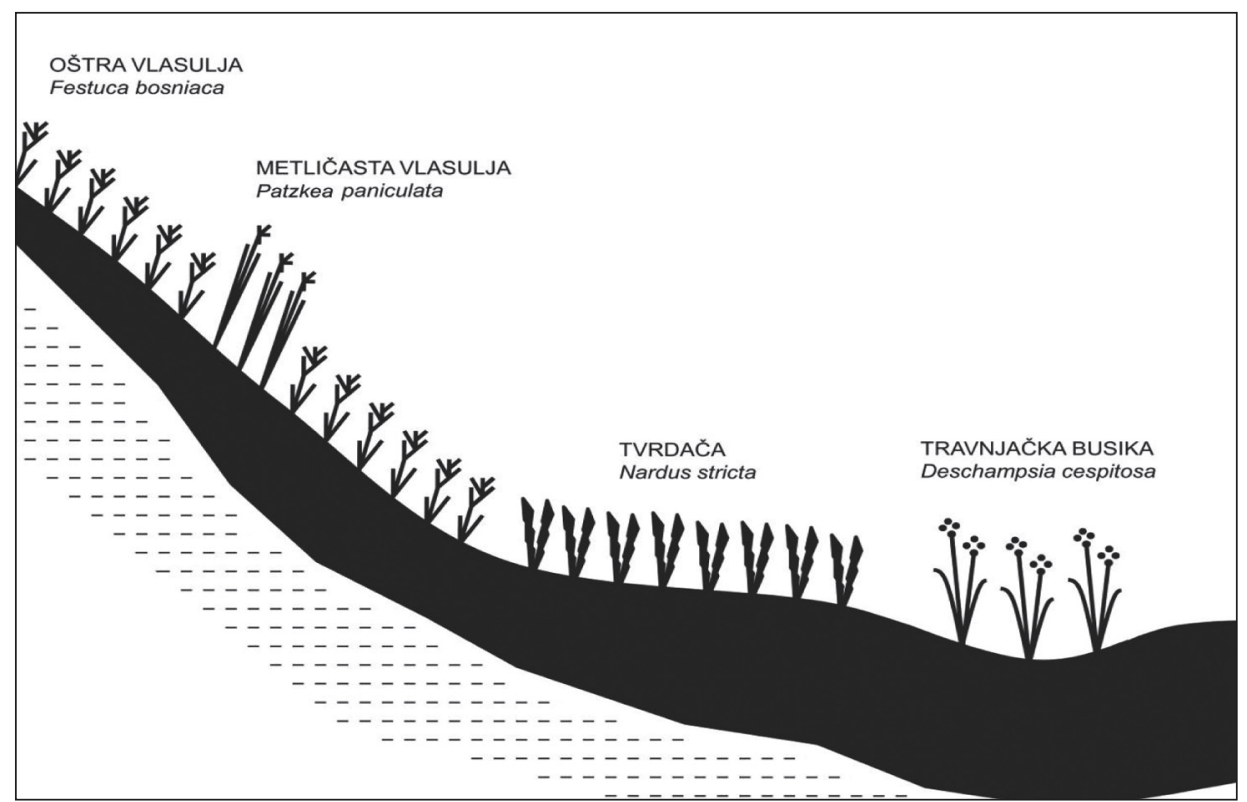

S1. 5. Primjer travnjačkog profila na području Šegotskog padeža (izradio Nikola Koletić)

Sve dosad navedeno jasno upućuje da je u Nacionalnom parku Sjeverni Velebit u znatnoj mjeri prisutan negativni trend povezan s napredovanjem drvenaste i grmolike vegetacije na područjima svih tipova travnjaka, posljedica čega je gubitak biološke raznolikosti. Usporedbom kartografskih podloga iz 1975./1977. s recentnim satelitskim snimkama iz 2007. uočeno je da su u procesu prirodne vegetacijske sukcesije uslijed napuštanja tradicionalnog stočarstva površine travnjačkih staništa u Nacionalnom parku Sjeverni Velebit smanjene s 12,53 \% ukupne površine Parka na 8,24 \% ${ }^{22}$. U tom relativno kratkom razdoblju zaraslo je 508 ha, odnosno $34 \%$ nekadašnjih travnjaka. Najčešće su sukcesijom zahvaćeni rubni dijelovi travnjaka na koje postepeno ulaze drvenaste vrste. Rezultati naših istraživanja ukazuju da je sukcesija brža na travnjacima primorske padine planine, nego na travnjacima vršne zone planine. Na višim nadmorskim visinama sukcesija je sporija zbog kraćeg vegetacijskog perioda, oštrije klime, izloženosti buri te prostranijih travnjaka koji sporije zarastaju od manjih, fragmentiranih travnjaka na nižim nadmorskim visinama.

${ }^{22}$ R. PERNAR et al., 2010. 
Tabl. 1. Drvenaste biljne vrste koje sudjeluju u sukcesiji travnjaka Nacionalnog parka Sjeverni Velebit

\begin{tabular}{|c|c|}
\hline Tip travnjaka & Drvenaste vrste u sukcesiji \\
\hline $\begin{array}{c}\text { kamenjarski pašnjaci šaša crljenike } \\
\text { i žute krške zečine }\end{array}$ & $\begin{array}{l}\text { šmrika (Juniperus oxycedrus), crni jasen (Fraxinus } \\
\text { ornus), crni bor (Pinus nigra), smrdljiva borovica } \\
\text { (Juniperus sabina), merala (Amelanchier ovalis), } \\
\text { srednja krkavina (Rhamus intermedia), glog (Crataegus } \\
\text { monogyna), rašeljka (Prunus mahaleb), crni grab } \\
\text { (Ostrya carpinifolia), drijenak (Cornus mas), sinja ruža } \\
\text { (Rosa glauca) }\end{array}$ \\
\hline $\begin{array}{l}\text { kamenjarski pašnjaci vriska i šaša } \\
\text { crljenike }\end{array}$ & $\begin{array}{l}\text { patuljasta borovnica (Juniperus communis subsp. } \\
\text { nana), smrdljiva borovica (Juniperus sabina), crni } \\
\text { bor (Pinus nigra), bor krivulj (Pinus mugo), jarebika } \\
\text { (Sorbus aucuparia) }\end{array}$ \\
\hline $\begin{array}{c}\text { travnjaci isprekidane šašike i šaša } \\
\text { crljenike }\end{array}$ & $\begin{array}{l}\text { medvjetka (Arctostaphylos uva-ursi), patuljasta } \\
\text { borovica (Juniperus communis subsp. nana, merala } \\
\text { (Amelanchier ovalis), dunjarica (Cotoneaster } \\
\text { integerrimus), smrdljiva borovica (Juniperus sabina), } \\
\text { jarebika (Sorbus aria agg.), smreka (Picea abies), crni } \\
\text { bor (Pinus nigra) }\end{array}$ \\
\hline travnjaci s uspravnim ovsikom & $\begin{array}{l}\text { crni bor (Pinus nigra), javor gluhač (Acer obtusatum), } \\
\text { jarebike (Sorbus aria agg. i S. aucuparia), patuljasta } \\
\text { borovica (Juniperus communis subsp. nana), malina } \\
\text { (Rubus idaeus), trnovita ruža (Rosa pimpinellifolia) }\end{array}$ \\
\hline travnjaci oštre vlasulje & $\begin{array}{l}\text { smreka (Picea abies), zrakasta žutilovka (Genista } \\
\text { radiata), patuljasta borovica (Juniperus communis } \\
\text { subsp. nana) i medvjetka (Arctostaphyllos uva-ursi) }\end{array}$ \\
\hline travnjaci metličaste vlasulje & bez zarastanja \\
\hline travnjaci tvrdače & patuljasta borovica (Juniperus communis subsp. nana) \\
\hline pretplaninski travnjaci busike & bez zarastanja \\
\hline $\begin{array}{l}\text { travnjaci s uspravnim ovsikom i } \\
\text { šašom crljenikom }\end{array}$ & patuljasta borovica (Juniperus communis subsp. nana) \\
\hline
\end{tabular}




\section{Zaključak}

Travnjake Nacionalnog parka Sjeverni Velebit čini raznolik skup zajednica uvjetovanih različitim čimbenicima (nadmorska visina, utjecaj bure, skeletnost tla, kiselost tla, nagib terena) i karakteriziranih različitim skupovima vrsta koje bioraznolikosti sjevernog Velebita pridonose na više razina - pejzažnoj, stanišnoj i vrsnoj (s obzirom na to da je velik broj vrsta vezan isključivo za travnjačka staništa). Travnjaci ujedno govore i o prošlosti čitavog područja, načinu života, privređivanja i kretanja te čine neizostavan i nemjerljivo važan dio prirodne i kulturne baštine. Zbog dramatične depopulacije Podgorja unazad sto godina i potpunog prestanka stočarenja nakon Drugoga svjetskog rata, travnjaci su počeli prerastati u grmlje i drveće. Procesi sukcesije razlikuju se brzinom i vrstama koje u njemu sudjeluju ovisno o tipu travnjaka. Načelno je sukcesija brža na travnjacima primorske padine u odnosu na vršnu zonu. Mjere aktivnog očuvanja travnjaka morale bi uključivati povratak ispaše, košnju i uklanjanje drvenastih vrsta, uz uvažavanje specifičnosti svakoga stanišnog tipa.

\section{Literatura}

Jan J. BARKMAN - H. DOING - Samuel SEGAL, Kritische Bemerkungen und Vorschläge zur quantitativen Vegetationsanalyse, Acta Botanica Neerlandica, 13, 1964, 394-419.

Joso BRAJKOVIĆ, Dosadašnje i potencijalne djelatnosti u Velebitskom primorju i Podgorju, Senjski zbornik, 44, Senj, 2017, 195-214.

Josias BRAUN-BLANQUET, Pflanzensoziologie, Grundzüge der Vegetationskunde, Berlin, 1964.

Hartmut DIERSCHKE, Pflanzensoziologie. Grundlagen und Methoden, Stuttgart, 1994. Heinz ELLENBERG, Vegetation Ecology of Central Europe, Cambridge, 1988.

Sabine F. FISCHER - Peter POSCHLOD - Burhard BEINLICH, Experimental studies on the dispersal of plants and animals on sheep in calcareous grasslands, Journal of Applied Ecology, 33, 1996, 1206-1222.

Ivo HORVAT, Brdske livade i vrištine u Hrvatskoj, Acta Botanica Croatica, 6, 1931, 76-90.

Ivo HORVAT, Vegetacijske studije o hrvatskim planinama. I. Zadruge na planinskim goletima, Rad JAZU, 238, 1930, 1-96.

Ivo HORVAT - Vjekoslav GLAVAČ - Heinz ELLENBERG, Vegetation Südosteuropas, Stuttgart, 1974. 
Michael J. HUTCHINGS - Alan J. A. STEWART, Calcareous grasslands, u: Martin R. PERROW - Anthony J. DAVY: Handbook of Ecological Restoration. Vol. 2. Restoration in Practice, Cambridge, 2002.

Matija KALIGARIČ - Metka CULIBERG - Branko KRAMBERGER, Recent vegetation history of the North Adriatic grasslands: expansion and decay of an anthropogenic habitat, Folia Geobotanica, 41, 2006, 241-258.

Matija KALIGARIČ - Jožica BRECL - Sanja ŠKORNIK, High potential of subMediterranean dry grasslands for sheep epizoochory, Open LifeScience, 11, 2016, 177-184.

Mladen KLEMENČIĆ, Poimanje i temeljna zemljopisna obilježja Podgorja, Senjski zbornik, 44, Senj, 2017, 5-16.

Mirko MARKOVIĆ, Stočarska kretanja na Dinarskim planinama, Zbornik za NŽO JAZU, 45, 1971, 523-550.

Mirko MARKOVIĆ, Sezonska stočarska naselja na Dinarskim planinama, Zbornik za NŽO JAZU, 46, 1975, 253-296.

Mirko MARKOVIĆ, Narodni život i običaji sezonskih stočara na Velebitu, Zbornik za NŽO JAZU, 48, 1980, 5-139.

Mirko MARKOVIĆ, Stočarska kretanja na Dinarskim planinama, Zagreb, 2003.

Vasilios P. PAPANASTASIS - Dimitrios CHOUVARDAS, Application of the stateand-transition approach to conservation management of a grazed Mediterranean landscape in Greece, Israelian Journal of Plant Science, 53(3-4), 2005, 191202.

Renata PERNAR - Ante SELETKOVIĆ - Mario ANČIĆ - Jelena SUČIĆ, Kartiranje travnjaka, utvrđivanje promjena travnjačkih površina i izrada karte pokrova zemljišta u NP Sjeverni Velebit, Zagreb, 2010.

Pravilnik o popisu stanišnih tipova, karti staništa te ugroženim i rijetkim stanišnim tipovima, Narodne novine 88/14, 2014.

Željko POLJAK, Velebit, Zagreb, 1969.

Ivo TRINAJSTIĆ, Biljne zajednice Republike Hrvatske, Zagreb, 2008.

Ivo TURK - Nikola ŠIMUNIĆ - Nenad POKOS, Suvremena demografska obilježja Podgorja, Senjski zbornik, 44, Senj, 2017, 73-96.

\section{Internetski izvori}

Flora Croatica, URL: https://hirc.botanic.hr/fcd/beta/map/distribution (2019-09-01)

The Plant List, URL: http://www.theplantlist.org/ (2019-09-01) 


\section{DIVERSITY AND ENDANGERMENT OF THE GRASSLANDS OF THE NORTHERN VELEBIT NATIONAL PARK}

\section{Summary}

The grasslands of the Northern Velebit National Park are for the most part not a primary type of vegetation, however, they came about as a consequence of human activity by deforestation, burning, grazing and mowing.

This process began several millennia ago and has continuously maintained the balance between the forest and grasslands, and it has resulted in a greater biodiversity than what would have been in the untouched natural state. In the second half of the $20^{\text {th }}$ century, traditional seasonal transhumant vertical migrations of people and livestock from Podgorje to the Velebit summer pastures were discontinued as a consequence of the great depopulation of Podgorje, which today is the least populated region in Croatia. Studies of the vegetation of the grasslands within the park during 2009 and 2010 indicated the large diversity of the grasslands which differ from one another depending on the above sea level altitude, relief of the terrain, features of the soil, influence of the wind and the former usage of the land. Succession, in other words, the encroachment of the grassland areas by woody and shrubby species was noted over almost all types of grassland, however, the intensity of the succesion and also the species which grow depend on the type of grassland. Succession is significantly slower on grasslands in the upper zones than on grasslands of the littoral slopes, due to the shorter vegetation period, the harsher climate, the exposure to the strong bura wind and wider grasslands which under hihger succession pressure than the smaller, fragmented grasslands that we come across at the lower altitudes. The conservation of grasslands would have to be a priority for the park's management, because besides the exceptional biodiversity, the grasslands also tell us about the history of the whole region, the way of life, the economy and the movements, and makes up an essential and immeasurable important part of both the natural and cultural heritage.

Keywords: pastures, succession, transhumance, grazing 